\title{
MODERN MUSICOLOGY RESEARCH: GAME THEORY PROJECTIONS
}

\section{Kateryna Fadyeyeva}

\section{INTRODUCTION}

In the history of the development of mathematical science, the theoreticalgame principles can be traced over a long period of time, which is measured over several centuries. The Game theory has numerous fields of application in those areas of knowledge where the condition of uncertainty, stochasticity is manifested. Extrapolation of the theoretical-game regularities to the study of composer's creativity allows us to find out the logical-constructive principles of musical thinking, associated with combinatorics and probability.

The relevance of the topic of the study is determined by the nature of contemporary composer's thinking, the updating of composer techniques, the searches and the combination of various sound-producing means in the context of the theoretical-probabilistic, random (stochastic) processes, with focusing attention on game regularities in mechanisms of musical thinking.

The purpose of the research is to study the manifestation of the theorygame regularities in the composer's creativity.

The analysis of the musical text in the projection of probability theory and the theory of games provides an opportunity to study logical-constructive regularities in composer's thinking.

The origins of the principles of the mathematical probability theory were first discovered on examples of gambling and games in dice that were found in archival documents of correspondence of B. Pascal and P. Fermat dated July 29,1654 . It is up to this date that the emergence of the theory of games as a mathematical discipline can be attributed. At the categorical level of scientific knowledge, the concept of "probability" reflects a special type of relationships between phenomena that characterize the processes indicated by the sign of multiplicity. In connection with the above, let us note that the theory of probability as a mathematical science reveals the regularities that arise in the interaction of a significant number of random factors in the form of a qualitatively peculiar connection between random and necessary. Based on the above theoretical-probabilistic definitions and regularities, it is important to note that apart from the various connections within the limits of mathematical probability the game theory has numerous applications outside of it, mainly in those branches of knowledge where is the condition of uncertainty is manifested. The theory of games was created by studies of 
Ch. Waldegrave (1712), D. Bernoulli (1732), P. Laplace (1814), J. Bertrand, E. Zermelo (1911), E. Borel (1921), J. Neumann (1928), O. Morgenstern.

Besides the various connections within Mathematics itself, the game theory has numerous applications beyond it, mainly in those areas of knowledge where uncertainly is encountered.

\section{Patterns of game theory in theoretical musicology. Analytical retrospections}

Game patterns in musicology are manifested in the folk polyphony. Thus, in J. Hominsky's study "The History of Harmony and counterpoint" it was noted that in the Ukrainian and Russian folklore the heterophonic kind if polyphony was most developed, characterized by simultaneous combinations of different variants of the same melody with vocal, instrumental or mixed performance. In the process of performance there is an element of spontaneity, which is caused by the creative capabilities of the performers, improvisation, integrated with the means of musical expression ${ }^{1}$.

Investigating the logical-constructive processes in composer's work it turned out to be important for us that the theoretical game regularities were used in the art science in the work of composer Ia. Xenakis "Formalized areas of music"2. Thus, in particular, in the third chapter, named "Musical Strategy", the principles of a musical composition, created by two groups of performers in accordance with the principles of the game theory, are set forth. The use of gaming factors allows us to generalize that this is a spontaneous, stochastic process, where each state determines the strategy of the game, which is conducted in accordance with the matrix of the transition.

In the composition of Ia. Xenakis "Strategy" for two orchestras the composer uses a game concept based on combinatorial principles. In this work the game situation is manifested in the duration and speed of combinatorial combinations.

The concept of the analysis of academic professional composer creativity, which is considered in connection with the system-structural method of analysis of composer's personality, is proposed by A. Mukha in the study "The Process of Composer's Creativity"3. The processuality of the artist's work is directed at the composition of the musical work which is determined by structural elements and dynamic development (from the initial to the final

\footnotetext{
${ }^{1}$ Hominsky, J. (1975, 1979). Istorija gharmoniji ta kontrapunktu. Kyiv: Muzychna Ukraina. (Vols. 1, 2).

${ }^{2}$ Xenakis, Ia. (1971). Formalized Music thought and mathematics in composition. London: Indiana University Press, Bloomington.

${ }^{3}$ Mukha, A.I. (1979). Protsess kompozitorskogo tvorchestva: problemy i puti issledovaniya. Kyiv: Muzychna Ukraina.
} 
stage). The most important, value component of the creative process is the process of choosing the appropriate option which arises spontaneously or improvisationally. Harmonious design of variants of a musical form depends on factors of the creative method, stylistic features, system of creative guides. A. Mukha applies theoretic-game regularities to the logical-constructive principles of musical thinking, focusing attention on rational moments in the creative process where the composer's individuality, figurative content, the system of representations, taking into account traditions and previous experience, are interrelated.

Ye. Nazaykinsky's study "The logic of musical composition" ${ }^{4}$ is devoted to the study of the laws and compositional principles of European professional instrumental music (on the example of the sonata-symphonic genre and instrumental miniature) in combination with the peculiarities of musical creativity, performing culture and perception of musical culture of the twentieth century.

In the context of our study, the fourth chapter of the above work, where the theoretical and game laws are considered, is of a particular interest. Thus, Ye. Nazaykinsky defines three main groups of functions that are characteristic of the composition of a work of art - a group of "communicative", a group of tectonic ("formative") and a group of meaningful and semantic functions. The most typical ones based on the general logic of development of the development material are dialogic and monological logic. The foresight offered by the musicologist explores the incorporation of game logic, which in the process of thematic development is determined by the laws of composition and reproduces it in intonation forms. Game logic uses one of the following forms - polylog, dialogue, monologue, or moves from one to the other. Analysis of instrumental works by D. Scarlatti, J. K. Bach, J. Haydn, W. A. Mozart, R. Schuman, F. Chopin, P. Tchaikovsky, S. Rachmaninov, I. Stravinsky demonstrated that game logic was not formed in the development, but in the initial sections of the form and integrated with the logic of exposure.

Structural aspect of the use of game-theoretical regularities is proposed by L. Akopyan in the article "Initial principles of formalized analysis of musical text" ${ }^{\text {"5 }}$. The author examines paradigmatic (a number of segments with repeating structures that are grouped into a certain number of paradigms) and syntactic (a unit of musical text, endowed with a more complex structure than

\footnotetext{
${ }^{4}$ Nazaykinsky, Ye.V. (1982). Logika muzykal'noy kompozitsii. Moscow: Musyka.

${ }^{5}$ Akopyan, L.O. (1986). Iskhodnye printsipy formalizovannogo analiza muzykal'nogo teksta. In Strukturnyy analiz teksta: sb. statey AN Armyanskoy SSR, 2. Yerevan: AN Armyanskoy SSR (pp. 210-220).
} 
a segment of the motive level), weak and strong positions of musical text, which are in the process of complex game.

\section{Patterns of game theory in the creativity of contemporary Ukrainian composers}

Analyzing modern studies that consider the inclusion of game regularities into the process of creating a musical composition, let us refer to the article by Alexei Skrypnyk "The phenomenon of aleatory in the work of composers of the twentieth century: the aesthetic and cultural aspect" $"$ where the trends of the development of musical art, which are associated with scientific achievements: the development of the universe as an evolving system, changes in the perceptions of the functioning of space and time, the macrocosm and the microcosm in the twentieth century, which influenced the character of the composer's thinking, are considered. According to the author of the article, the result of the above factors "... was a radical renewal of expressive means, techniques of composition aimed at reflecting the latest life impulses, events squeezed in time with their unusually high informative saturation, rapid dynamics of emotional and psychological processes" ${ }^{, 7}$.

O. Skrypnyk notes the most popular composer techniques: seriality, serial, sonoristics, micropolyphonia, pointillism and aleatory. In determining of the phenomenon of aleatory the author of the article gives a variety of areas of its interpretation in the works of musicologists - as a direction, method of composition, writing technique, directly musical composition, characteristics of the creative and performing process, provided by modern researchers P. Boulez, Ct. Kohoutek, E. Denisov, Yu. Kholopov, D. Shulgin, S. Pavlyshyn, L. Entelis, O. Sokolov, N. Gulianitskaya. The key principle of aleatory is "... the principle of randomness, which follows from the etymology of the term itself: "aleatory" from the Latin "alea" - a dice, lot, randomness"

The appearance of aleatory was associated with philosophical, culturological, social, psychological processes of the twentieth century ${ }^{9}$. The author of the article, considering the philosophical aspect of the problem of the origin and development of aleatory technique in the works of representatives of various composer schools, noted that the beginning of the twentieth century was marked by the doctrine of the noosphere by P. Teilhard de Chardin and V. Vernadsky as the spiritualized energy sphere of the

${ }^{6}$ Skrypnik, A. (2009). Fenomen aleatoriki v tvorchestve kompozitorov XX veka: estetikokul'turologicheskiy aspekt. Naukovyi visnyk Natsionalnoi muzychnoi akademii Ukrainy imeni P.I. Chaikovskoho, 75: Kompozytor i suchasne sotsiokulturne seredovyshche, 155-171.

\footnotetext{
${ }^{7}$ Ibid., p. 155.

${ }^{8}$ Ibid., p. $155-156$.

${ }^{9}$ Ibid., p. 156.
} 
macrocosm, integrated with the individual microcosm of the composer. An example of the embodiment of cosmic ideas is the work of A. Skryabin, in particular, his composer's technique. In the thinking of A. Skryabin irrationality is associated with the manifestation of randomness, plurality, variability. An important element in understanding the origin of randomness is a synergetics, which supposes a constructive factor in the processes of self-organization ${ }^{10}$.

The philosophical understanding of randomness is associated with two types of randomness, namely, randomness which produces multiplicity options and randomness producing uncertainty. The effect of randomness on the macro level is related to the inclusion in the dynamic system, marked by the state of instability that is characteristic for musical art of the second half of the twentieth century. Herewith, the randomness causes endless replication with infinite multiplicity of variant opportunities and unpredictability. It is the modern philosophical interpretation of randomness that allows "... to substantiate the aesthetic nature of aleatory in artistic creativity, to understand the underlying causes and mechanisms of its manifestation in musical art"11. Among the factors of occurrence of aleatory the game one is considered to be important, accumulating probabilistic plurality, unpredictability, randomness. Game regularities, the key principle of which is randomness, were used by John Cage in the composition process involving gambling bones, maps, ancient Chinese book of fortune telling (The Book of Changes - I Ching). It is J. Cage who in the creation of the aleatory composition uses the principles of the game theory, associated with stochasticity of sound process. The game components of the aleatory composition are used as a constant model with the regulation of all parameters, that are characteristic for the creativity of J. Cage and K. Stockhausen, where stochasticity is associated with "unlimitedness", "totality"12.

The game components of the "limited", "controlled" action are used in the aleatory compositions of Ukrainian composers Y. Stankovych, V. Silvestrov, G. Lyashenko, I. Karabits, V. Zubytsky, M. Kovalinas, V. Runchak, O. Skrypnyk and West European composers P. Boulez, W. Lutosławski. Game principles are manifested in the improvisation of instrumental parties of orchestral groups, dynamic plans, colorist, stroke and nuanced techniques. In the above-indicated article O. Skrypnyk analyzes several works:

\footnotetext{
${ }^{10}$ Skrypnik, A. (2009). Fenomen aleatoriki v tvorchestve kompozitorov XX veka: estetikokul'turologicheskiy aspekt. Naukovyi visnyk Natsionalnoi muzychnoi akademii Ukrainy imeni P.I. Chaikovskoho, 75: Kompozytor i suchasne sotsiokulturne seredovyshche, 155-171.

${ }^{11}$ Ibid., p. 159.

${ }^{12}$ Ibid., p. 163.
} 
"Concert No. 1 for Piano and Strings" (1979), "Penitent verse for Violin and String Orchestra" (1989), "Aria-Passiona 2" (Chamber Symphony No. 3 for viola and Chamber Orchestra) (2000). Igor Shcherbakov uses game components fragmentary in the context of the principles of limited aleatory technique. "Indeterminate" musical episodes create “... a necessary psychological or colour background" in one case; in the other, they invade the dramaturgic process, introducing "imaginary" freedom into a well-thought-out algorithm of the work"13.

In the Concert No. 1 for piano and strings (tact 24-25) in a cello party (in the form of squares), " $\ldots$ the composer captures movement from note to note using glissando"14. The gaming components are found in the variant performing interpretation, in the dialogic form of interaction between the orchestral and piano parties ${ }^{15}$. In the party of violins (tact 49-50, 53) “... the composer uses squares of Pizzicato. Despite the precise sound-pitch definition and the sufficiently expressive metric introduction of voices, the absence of rhythmic differentiation $<\ldots>$ "the game components are freely interpreted by the performers of durations ${ }^{16}$. The game elements change the semantic results of identical methods of aleatory technique "... the canonical introduction of voices, designed in the form of squares, provides for free metric reading by performers within the tact" ${ }^{\prime 17}$.

The game elements are manifested in dynamic changes from (pianissimo crescendo - to four forte), which is achieved using the movement of the sonorous stratum. In Quasi Cadenza the aleatory game (tact 191-196) is traced in the piano solo, the technique of microchromaticity of all instruments, undifferentiated sound flow, creating the effect of the sonorous mass. The game is also manifested in the constant change of metric introductions, denoted by a square in the parties of performers, which implies interpretative variability ${ }^{18}$. In addition, the author of the article focuses on the manifestation of game factors in the artistic concept of the work - in comprehension of “... multi-directional flows of time in the complex plexus of the present, past and future, closed in the horizontal-vertical projection of the reflective consciousness"19.

${ }^{13}$ Skrypnik, A. (2009). Fenomen aleatoriki v tvorchestve kompozitorov XX veka: estetikokul'turologicheskiy aspekt. Naukovyi visnyk Natsionalnoi muzychnoi akademii Ukrainy imeni P.I. Chaikovskoho, 75: Kompozytor i suchasne sotsiokulturne seredovyshche, 155-171.

${ }^{14}$ Ibid., p. 165.

${ }^{15}$ Ibid.

${ }^{16}$ Ibid., pp. 165-166.

${ }^{17}$ Ibid., p. 165.

${ }^{18}$ Ibid., p. 166.

${ }^{19}$ Ibid. 
In the work of I. Shcherbakov "Repentant verse" for violin and string orchestra O. Skrypnyk notes the fragmentary use of aleatory. The composer' activates game elements "... as a dynamic crescendo in the form of squares with a certain rhythmic formula in the diagonal texture (tact 46-55) of the entire orchestra, except violins (1-2) of the group of first violins" ${ }^{\text {"20 }}$. The manifestations of the principles of the game are connected with the time of the introduction of instruments and improvisation in the process of performing, and the diagonal texture increase in combination "... with autonomous rhythmic formulas create expressive aleatory-sonorous stratum that is moving" 21 .

The composer "plays" with the rhythmic formulas, the texture-sonorous strata, the number of notes in squares of various groups of instruments, the regulation of the time "... of the sounding of mobile fragments $<\ldots$.. " within the limits of one tact, the regulation of the sounding of a square with the quantity designation of beats in the tact (tact 58 and 60) ${ }^{22}$. The game is traced in a dynamic plan: ".. a metric displacement, which depends on the free reading of the pace (speed) of the squares (four note durations in each square thirty second) creates the impression of the arbitrariness of the performing fragment" (tact 63-66) ${ }^{23}$. O. Skrypnyk focuses on the soloist's party (tact 64, 67-72) and in Quasi cadenza (tact 96, 98-99, 101), in which “... a rhythmic acceleration is written during one tact or a certain number of beats in a tact. It begins conditionally, from eighth durations and ends with thirty second durations. The composer accurately fixes the sound-pitch, controls the timing of rhythmic accelerations (within the limits of the tact or a certain amount of beats within the tact), but writes out the randomness of the number of repetitions by the notegraphy. The soloist decides on his own the need of one or another number of rhythmic repetitions, and each time during a new performance the number of repetitions may change" ${ }^{24}$. This is where the elements of the game in the party of the soloist are revealed and, in addition, the composer uses the elements of the game in the dramaturgic plan of the work“... in preculminating" (orchestra) and culminating (soloist) zones ..."25.

In the work "Aria-Passiont 2" (Chamber Symphony No. 3 for viola and chamber orchestra) of I. Shcherbakov the game elements of the aleatory technique appear fragmentarily, using three times the "... squares in the score

${ }^{20}$ Skrypnik, A. (2009). Fenomen aleatoriki v tvorchestve kompozitorov XX veka: estetikokul'turologicheskiy aspekt. Naukovyi visnyk Natsionalnoi muzychnoi akademii Ukrainy imeni P.I. Chaikovskoho, 75: Kompozytor i suchasne sotsiokulturne seredovyshche, p. 166.

${ }^{21}$ Ibid., p. 167.

${ }^{22}$ Ibid.

${ }^{23}$ Ibid..

${ }^{24}$ Ibid., p. 168.

${ }^{25}$ Ibid., p. 167. 
(tact 16, 19, 22) of the first violins, second violins and altos within a tact, when reproduced with the use of canonical introduction (textured crescendo), free readings of the pace by the performers, create each time lit in a new way sound spots" ${ }^{\prime 26}$. The game principles are manifested in the colouristic change of the sonorous stratum with the invariable time of the introduction and the ending of sounding of the square.

In Ye. Kharchenko's article "The Phenomenon of the Game" in Piano Miniatures of the 1990-2000s (on the Example of Piano Works by K. Tsepkolenko, S. Pilyutikov, I. Shcherbakov)" ${ }^{\text {27 }}$ are revealed the peculiarities of forming the national concept of postmodernism in musical culture with a focus on piano creativity. In the context of contemporary problems of globalization, the vector of creativity of Ukrainian composers is connected with non-revival, spiritual search. Creative pursuits in both the days of classicism, romanticism, avant-garde and postmodern are indicated by the appeal to the genres of piano music. The foundations of Ukrainian postmodernism are based on the revival of baroque, classicist, romantic and avant-garde traditions. There is a re-arrangement of the images and forms of the past, the mixing of genres and styles; the proportion of the intellectual component in creativity has been increased.

The modern cultural paradigm requires an update of the value system of coordinates. According to Ye. Kharchenko's definition: "The absurdity of modern life, its illusory, unnatural, chaotic nature, have provoked an elevated postmodern game style. Such a characteristic feature is drawn by many musicologists and searches in the field of contemporary creativity of Ukrainian composers"28. New piano works by contemporary Ukrainian composers illustrate the idea of the interaction between game and music.

In the context of the typological principle, the game factor applies Karmella Tsepkolenko, introducing the line of I. Stravinsky and S. Prokofiev. Samples of "phenomenon of game" in musical art are shown by S. Pilyutikov and I. Shcherbakov.

In K. Tsepkolenko's play "Evening Solitaire" (otherwise called "Card Game № 2") the principle of play is mediated through performance as an aesthetic manifestation of the "art of action". The composer uses the

${ }^{26}$ Skrypnik, A. (2009). Fenomen aleatoriki v tvorchestve kompozitorov XX veka: estetikokul'turologicheskiy aspekt. Naukovyi visnyk Natsionalnoi muzychnoi akademii Ukrainy imeni P.I. Chaikovskoho, 75: Kompozytor i suchasne sotsiokulturne seredovyshche, p. 168.

${ }^{27}$ Kharchenko, Ye. (2009). "Fenomen ghry" u fortepiannykh miniatjurakh 1990-2000-kh rr. (na prykladi fortepiannykh tvoriv K. Cepkolenko, S. Piljutykova, I. Shherbakova). Naukovyi visnyk Natsionalnoi muzychnoi akademii Ukrainy imeni P. I. Chaikovskoho, 84: Kompozytor i suchasnistj, 130-142.

${ }^{28}$ Ibid., p. 133. 
principles of playing in the form of solitaire decomposition and "ejection of cards" by the performer-pianist, that is indicated in the note text, figuratively dramatic plan forms the use of rhythmic pedal technique that corresponds to certain musical durations. The play is manifested in the use of temporal and acoustic spaces, combination of free atonality with the stage, theatricality.

In the work "From the Blues" by Karmella Tsepkolenko, as the author of the article notes, the game manifests itself in nostalgia "by the value criteria of earlier eras" 29 . Using the performance genre, the composer presents the blues in an avant-garde manner; combines sonoristics with jazz-style chords; piano improvisation articulated by the logic of the development of musical thought with a performance situational game.

K. Tsepkolenko in her work "Landscape-Solo" represents a game with figurative-listening and performing associative thinking. To reproduce the landscape, a system of "musical and expressive resources" is involved ${ }^{30}$ with giving at the end of the work "used system of symbols and abbreviations" 31 . The coloristic nature of sound resources is linked to the imaginative realm of the landscape, and the solo integrates an in-depth psychology with the instrumental content of the work. The composer does not limit the performer's imaginative and associative thinking and gives him the opportunity to use a free fantasy game. In addition, the elements of the game are assumed by the composer in the event of various performances.

The imaging sphere of the work is related to the seascape, the play elements of which are dramaturgy of two moods - calm and storm, embodied in two-part construction, tempo changes, vibrations of dynamic shades, different register sounds. The realization of the image-dramatic development is carried out by K. Tsepkolenko using the "game" of improvisationalchromatic technique for the reproduction of fragmentary movable ostinato, "sound blocks" that are formed into sound layers, created by the technique of controlled aleatory; also the pointillist technique is employed.

In the above article, Ye. Kharchenko analyzes the work "Play the game" by Sergei Pilyutikov, in which the musical space is represented in accordance with the game principles with the use of style play, aleatoric play of fragments and textured fabric. The author of the article states: "Here the concept of play is used in the sense of both playing the piano and aleatoric technique as

${ }^{29}$ Kharchenko, Ye. (2009). "Fenomen ghry" u fortepiannykh miniatjurakh 1990-2000-kh rr. (na prykladi fortepiannykh tvoriv K. Cepkolenko, S. Piljutykova, I. Shherbakova). Naukovyi visnyk Natsionalnoi muzychnoi akademii Ukrainy imeni P. I. Chaikovskoho, 84: Kompozytor i suchasnistj, p. 136.

${ }^{30}$ Ibid., p. 137.

${ }^{31}$ Ibid. 
playing with elements of a work" ${ }^{32}$. Composer's processing of sound elements is done by using combinatorial principles. Game principles are traced in the application of such techniques as pointillism, polyphonic bundles and agogic accents $^{33}$.

The composer's attention is focused on textures that are enriched by "small seconds from different sounds" ${ }^{34}$, one trill integrates with another, causing game finds with a sound vertical. According to the author, further development is determined by the transformation of "... vertical to horizontal" with the inclusion of the game "of different textural and rhythmic formations, four waves of development of the "game" with the game that are formed ${ }^{35}$.

In the work "Lullaby" by S. Pilyutikov, the properties of the game are realized by means of musical expressiveness. The composer develops the basic sound motif (complex) as a series, performs game variations with interval "overlays", their "clutches", transpositions, variations of major and minor. Interval overlays extend the textural and audio range. Changes in the color complex of the sound complex in each beat are made using polyphonic techniques, dynamic nuance, integration of pointillist technique with the development of melodic line. Game factor is manifested in aleatory, improvisation, dissonant harmonic layers ${ }^{36}$.

Analyzing Igor Shcherbakov's work "LiebesTod. Afterword" Ye. Kharchenko sees a manifestation of the play factor in a veiled conceptualism. The first part of the title encrypts the music of Western European composers, namely R. Wagner (opera "Tristan and Isolde"), the second part of the title is related to the properties of temporal space, where the dramatic "intonation-symbols" are concentrated ${ }^{37}$. The author of the article notes that "the composition is based on the leitons, themes and symbols that have passed through the age space and remain relevant to modern life (Sonata Op. 27 No. 2 cis-moll and motif of Fate from the Fifth Symphony by

${ }^{32}$ Kharchenko, Ye. (2009). "Fenomen ghry" u fortepiannykh miniatjurakh 1990-2000-kh rr. (na prykladi fortepiannykh tvoriv K. Cepkolenko, S. Piljutykova, I. Shherbakova). Naukovyi visnyk Natsionalnoi muzychnoi akademii Ukrainy imeni P. I. Chaikovskoho, 84: Kompozytor i suchasnistj, p. 138.

${ }^{33}$ Ibid., p. 139.

${ }^{34}$ Ibid.

${ }^{35}$ Ibid.

${ }^{36}$ Kharchenko, Ye. (2009). "Fenomen ghry" u fortepiannykh miniatjurakh 1990-2000-kh rr. (na prykladi fortepiannykh tvoriv K. Cepkolenko, S. Piljutykova, I. Shherbakova). Naukovyi visnyk Natsionalnoi muzychnoi akademii Ukrainy imeni P. I. Chaikovskoho, 84: Kompozytor i suchasnistj, p. 140.

${ }^{37}$ Ibid. 
L. van Beethoven, "Reflection" Intonations of "The Love Dreams" by F. Liszt)" ${ }^{38}$.

In a three-part reprise form the first part of the work is semantically linked to romantic keynotes - the music is encrusted with Isolde's leitem, the trio's rhythm base as an allusion to Sonata op. 27 No. 2 cis-moll by L. van Beethoven, "Flares" of F. Liszt's "Dream of Love",39.

The composer's "Everything is Blurry and smeared with Pedal" defines the playwriting of the second section. According to Ye. Kharchenko, for the reproduction of the "sound of Eternal time" the composer employs a pedal vibrato, a tremolo of reduced septa chords, to embody the sonar effect associated with temporal space ${ }^{40}$. Through the textural injection erupts the "Fate motif" of L. van Beethoven's Fifth Symphony <... >“411.

In the third section of the code, the composer includes all of the previously involved "leytinton structures and "blurs" the musical fabric of tremolo", in which the Fate motif sounds till the last tact"

Game patterns in the work are manifested in the philosophical understanding and comprehension of historical events; images of the past are encrusted in the "text of modern musical language" ${ }^{43}$. The trends of musical postmodernism synthesize the creative discoveries of previous eras.

The concept of scientific investigation of Bogdana Maksymenko "Rational and intuitive in the work of Vitaly Hodzyatsky "Game" is based on the principle of manifestation of the synthesis of intellectual and creative maxims. The work "Game" completes the cycle "Characteristic scenes", which includes seven plays - "portrait sketches of someone from the author's close people" 44 . The focus of the study is due to the programmatics of the work "Game", which is represented by the duality of rational and intuitive. Rational principles are related to game principles, and intuitive, in accordance, to the creative. Rational maxims in the work are realized for the use of stable structural elements, quantitatively limited, that are used in the sequence defined by the composer. As a stable output constant, a twelve-tone scale with a division into two sound combinational sequence is detected. The central

${ }^{38}$ Kharchenko, Ye. (2009). "Fenomen ghry" u fortepiannykh miniatjurakh 1990-2000-kh rr. (na prykladi fortepiannykh tvoriv K. Cepkolenko, S. Piljutykova, I. Shherbakova). Naukovyi visnyk Natsionalnoi muzychnoi akademii Ukrainy imeni P. I. Chaikovskoho, 84: Kompozytor i suchasnistj, p. 141.

${ }^{39}$ Ibid.

${ }^{40} \mathrm{Ibid}$.

${ }^{41}$ Ibid.

${ }^{42}$ Ibid.

${ }^{43}$ Ibid.

${ }^{44}$ Shurova, N.S. (1999). Vitaliy Godzyatskiy. Shtrikhi k portretu. Green Lamp, 3-4, 50-51. 
structure-forming element, according to the conception of V. Hodzyatsky, is a twelve-tone scale as the key principle of predecaphonical technique.

The elements of the game are two sound-pitch structures: the first "sound combination" is the alternation of the sound "a" with the big tertsia "ges/B", and the second is the sequence of sounds "c-des-as-es-g-h-d-f-e" 45 .

The structural analysis, as the author of the article points out, allowed to reveal two plans of sound tissue, namely, the sound-pitch constant obstinate movement in the first combination and the sound-pitch "ostinato" in the free register location and the interval segment (step) of the second combination. The game strategy of the composer's composition is based on a combinatorial principle - it is the sound-pitch obstinate repetition in the first combination and the scale one in the second combination. At the same time, the iterations alternately change - rhythmically (in both structural combinations); with chords (part I of the work); consistently (part II of the work); by register (part II of the work) and metrically. Precisely metrical changes - the shift of emphasis, varying size (using the "eighth progression or regression between stressed beats") ${ }^{46}$. The above-mentioned strategy of deploying a musical work is the area of rational. Regarding the intuitive sphere, its manifestations consist in choosing variants of "obstinate sound combinations" (metrorhythmic and registering) ${ }^{47}$. The emergence of new variants depends on the creative imagination of the composer. The logic of composer thinking determines the sequence of variants of sound combinations and, by definition of B. Maksymenko, "... here it cannot do without a rational, thought-out general plan of musical form, which can be defined as a two-part with an enlarged (extended) second part ..."48. Thus, in particular, in relation to the formative dramaturgy in the first part of the work, "Game", the composer introduces into the sound material of the first combination elements of variability - the use of pause, various rhythms, analogously to the variantcombination process of thinking in chess. In the second combination, both temporal (horizontal) and spatial (vertical) parameters are involved.

Precisely the changes in the harmonic components form new sound systems that affect the texture variability of the sound tissue. The phenomenon of arches, the continuous game between the first and second parts is formed by the use of the beginning notes of the second sound combination at the end of the first part of the work and which creates an

${ }^{45}$ Maksymenko, B.O. (2008). Ratsionalne ta intuityvne u tvori Vitaliia Hodziatskoho "Hra". Naukovyi visnyk Natsionalnoi muzychnoi akademii Ukrainy imeni P.I. Chaikovskoho, 73: Muzychna tvorchist ta nauka v istorychnomu prostori, 219-226.

${ }^{46}$ Ibid., p. 221.

${ }^{47}$ Ibid., p. 222.

${ }^{48}$ Ibid. 
integral deployment of the second part, simulating the game. And in this process of the game, in contradistinction to the scale ostinato, the temporal parameter in the form of the rhythm of eighth (eighth rhythm), in integration with the inclusion of natural musical intonations, caesura pauses and variable size, is detected as more weighty.

Examining the sound deployment of the second combination, the author of the article (B. Maksymenko) notes that its melodic presentation "... moves in the opposite interval direction from the previous one"49, while as the choice of the interval step of the register location is constantly changing, depending on the previous presentation of the sound combination, which is the manifestation of the intuitive start of time-space.

The variational changes are the characteristic feature of the first combination of the second part - the shift of emphasis, the change of duration (for small) and the rhythmic complications of the picture (syncope, aligned duration in combination with dashed rhythm, which creates a game of stressed and unstressed beats of two sound elements of the combination ${ }^{50}$. The game factor in the work is manifested not by the causal logic but by the characterized by the author of the article (B. Maksymenko) as "kaleidoscopic" one ${ }^{51}$. The causeeffect relationships of the "kaleidoscopic" logic are manifested in the previous sound situation with the certain immutability of the original material of the composition. The composer creates musical structures marked by stability with the introduction of pattern variability, and the chord completion of the work combines the original "c" and the sounds of the second combination, which is evidence of the manifestation of the game component. The analysis given by the author of the considered scientific investigation allows us to draw conclusions about the existence of logical-constructive principles of musical thinking in the creative work of V. Hodzyatsky, which are implemented by the composer using the laws of the intellectual game.

\section{Author's method of structural analysis of piano works by composers of the first third of the twentieth century:}

\section{A. Skryabin and M. Verykivsky}

In our study, the principles of game theory relate to combinatorics as a structural method of analyzing the A. Skryabin's harmonic system a system of large, not limited, as in classical music, number of elements that make it up.

\footnotetext{
${ }^{49}$ Maksymenko, B.O. (2008). Ratsionalne ta intuityvne u tvori Vitaliia Hodziatskoho "Hra". Naukovyi visnyk Natsionalnoi muzychnoi akademii Ukrainy imeni P.I. Chaikovskoho, 73: Muzychna tvorchist ta nauka v istorychnomu prostori, p. 224.

${ }^{50}$ Ibid.

${ }^{51}$ Ibid., p. 225.
} 
Chord structures vary in the number of sounds (from 3-tone to 12-tone structures), while at the same time in classical harmony it is mostly 3-4 sounds - triangles and septa-chords. Multi-sound chord structures (5-12 sound) - are varied in the mutual arrangement of sound elements in a harmonious vertical and texture-configuration horizontal.

The complicated type of harmonic system of A. Skryabin causes considerable individualization of textural and harmonic processes, which makes it necessary to apply a combinatorial method of analysis to the composer's creativity.

The essence of this structural method in information theory is that it represents one of the aspects of constructing and transforming the system of "messages" in the form of signs or in relation to our study of sounds. The regularities of combinatorics are related to the construction of elements of the original set, a derivative set called the combinatorial configuration. Such configurations include placement, rearrangement and connections.

The originality of A. Skryabin's late harmony lies precisely in the fact that each of the shortest in time exposures vertical projection of the textured complex forming any of the variants of the "Promethean" structure. That is, in multi-sound chord structures there is a leveling of the non-chord sounds that make up the "micro-vertical".

It should also be noted that in the chordal linkages of Late Skryabin's harmony, the dominant value belongs to voting, not harmoniously functional feature. Thus, its diversity is due, first of all, to interaction with textural factors of development. Multilingual chord structures can form an equirhythmic vertical, due to the integrated, almost "cluster" sounding, and A. Skryabin often used it in the works of later opuses.

The game regularities in our study are connected with combinatorics, as a structural method of analysis of piano creativity of A. Skryabin of the late period and piano creativity of M. Verykivsky, in particular, the discovery of certain properties of the harmonic language in the heritage of composers.

The study of the late-Skryabin harmonic system (on the example of Preludes, Op. 67 No. 1-2) using the combinatorial method of analysis and the author's heuristic computer program "MyAccord.exe." written in the programming language " $\mathrm{C}++$ ", allowed to find the manifestations of the game regularities and to make a number of important conclusions on the logical and constructive principles of musical thinking of the composer. Thus, the game factors in the late harmony of A. Skryabin are marked by an increase in quantity of sound-cells in chord structures (five, six, seven and more), which leads to an increase in the combinatorial variants of chord placement, and is accompanied by an exit beyond the boundaries of tertian texture.

However, with a considerable variety of constructively possible polyphonic chords in the work of A. Skryabin, namely in his late period 
(in comparison with classical and romantic harmony), there is a rather limited selection of sound elements and chords, their concrete-thematic implementation, which led to the formation of a "Promethean complex" not only at the level of individual chord structures, but also at the level of the integral construction of the work.

The obtained results of the study of harmonic language in the late period of the work of A. Skryabin make it possible to make the conclusion regarding the quality of the sound system that it is a compex-organizied orderly system with unequally probabilistic distribution of sound events values, which is manifested in combinatorial diversity, game principles, permutational changes in chord structures and intonation selection, the formation of an invariant centre in the form of "Prometheus complex". The idea of a combinatorial game is especially important in Skryabin's works, the difference of which lies in the variational-acoustic development of musical material.

The scientific novelty of the conducted research is to extrapolate the principles of the theory of games to the piano creativity of A. Skryabin of late period.

The unpredictability of the stochastic process, the variability, uniqueness, spontaneity that inherent in the game, are characterized by certain laws - the rules of the game, a kind of "algorithms" of a complex organized process.

It is this sense of "game", the unpredictability of the spontaneous process, which is perceived by the receptive consciousness in the music of the late period of A. Skryabin's creativity, which has direct confirmation in the study of combinatorial probabilistic-stochastic processes in the harmonic language of the composer.

The functioning of the game combinatorial principles of the organization of musical material is observed in the piano creativity of M. Verykivsky, in particular, in Preludes № 1 and № 11. The development of Prelude № 1 is determined by modulating sequential constructions (tact. 1-2), which in horizontal form reflect the structure of Skryabin's "Promethean chord". The use of the combinatorial method of analysis allowed to reveal the configurative game, permutative principles of the construction of musical tissue, which are assimilated with the idea of "Promethean complex". In the development of the musical material of Prelude № 11 the mode-scale principle of the non-accordion type is used with the inclusion of the elements of the mixolydian mode, the tonal discreteness, and the variability in the functioning of the invariant complex in the form of increased triplet-sound. The beginning of the Prelude (first line, tact. 1-2) is marked by a differentiated representation of the harmonic structure, which forms a diffuse complex-configurative structure in the subsequent game permutations (first line, tact № 3 and second line, tact № 1). Thus, in the development of this Prelude, a certain dynamics can be traced from the scale as an initial 
"code" with subsequent development in the form of the scale complex multiplicity and with its subsequent transformation into the polyphonic chords that form the simultate complex.

\section{CONCLUSIONS}

The research is focused on the analytical representation of the fields of application of the game theory in contemporary musicology. There were considered theoretical and musicological tendencies connected with the methods of exact sciences, in particular theoretical and game regularities with their extrapolation to composer's creativity, thematic development of the musical composition's form, structural and analytical study of musical works, study of logical and constructive principles of musical thinking.

Game patterns are also detected in folk polyphony. In Ukrainian and Russian folklore, heterophonical kind of polyphony has received the greatest development, which is characterized by simultaneous combination of different variants of the same melody with vocal, instrumental or mixed performance.

The main provisions of the theory of games were applied in musicology by a composer Iannis Xenakis for composing of his music. Two groups of musicians use the spontaneity in the process of perfomance, where each state determines the strategy of the game, which is conducted according to the matrix of the transition. The combinatorical principles are used a little differently in the composition "Strategy" by I. Xenakis for two orchestras, in which the game situation is shown through the duration and speed of execution of combinatorical combinations.

In the work of contemporary composers the principles of a game are embodied in using of diversified methods of dodecaphonic and aleatoric techniques, involvement of intellectual game patterns, temporal and acoustic spaces, integration of free atonality with the elements of theatricality and improvisation with performing situational game.

In the conditions of "information" complexity of the harmonic language of composers A. Skryabin (late period of piano creativity) and M. Verykivsky (piano creativity) heuristic computer technologies allowed to reveal internal connections between harmony and texture, to trace regularities, peculiar "algorythm" of the process in the musical thinking of composers, their logical and constructive principles.

The unpredictability of the stochastic process, the variability, uniqueness, spontaneity that inherent in the game, are characterized by certain laws - the rules of the game, a kind of "algorithms" of a complex organized process. It is this sense of "game", the unpredictability of the spontaneous process, which is perceived by the receptive consciousness in the music of the late period of A. Skryabin's creativity, which has direct confirmation in the study of combinatorial probabilistic-stochastic processes in the harmonic language of the composer. 
In the conditions of the "information" complexity of the harmonic language of such composers as A. Skryabin (late period of piano creativity) and M. Verykivsky (piano creativity), heuristic computer technologies allowed to reveal the internal connections between harmony and texture, to trace the regularities, the peculiar "algorithms" of the complex-organized process, penetrate into the mechanisms of the musical thinking of the composers, their logical-constructive principles. The unpredictability of the stochastic process, the variability, unrepeatability, and spontaneity which are inherent in the game, are characterized by the certain laws - the rules of the game.

Precisely in the study of the texture-harmonic system of A. Skryabin's late period of piano creativity and the piano creativity of M. Verykivsky the theoretical-game regularities are manifested in the projection of the dialogic level on the cause-effect dependencies, combinatorics of sound-cells and the manifestation of permutation. Extrapolation of the principles of game theory to the study of composer's creativity, with the focus on the principles of continuity in piano creativity of A. Skryabin and M. Verykivsky, allowed finding the manifestations of spontaneous and compositionally-conscious processes in the musical thinking of composers.

\section{SUMMARY}

The study deals the manifestation of the game theory regularities in composer work. The methodology of the research is in using the musicological, system-structural, probabilistic, game-theoretical and stochastic methods. This methodological approach allows to analyze the piano creativity of A. Skryabin and M. Verykivsky. The scientific novelty of the study is in extrapolation of the regularities of the games theory into the processes of musical thinking of A. Skryabin and M. Verykivsky with the discovery of their logical constructive principles and tendencies of continuity. In the conditions of the "information" complexity of the harmonic language of such composers of the first third of the twentieth century as A. Skryabin and M. Verykivsky, heuristic computer technologies allowed to reveal the internal connections between harmony and texture, to trace the regularities, the peculiar "algorithms" of the complex-organized process, penetrate into the mechanisms of the musical thinking of the composers, their logicalconstructive principles. The unpredictability of the stochastic process, the variability, unrepeatability, and spontaneity which are inherent in the game, are characterized by the certain laws - the rules of the game. In the study of the texture-harmonic system of the late period of piano creativity of A. Skryabin and the piano creativity of M. Verykivsky, the theoretical game regularities are manifested in the projection of the dialogical level of causeeffect dependence, combinatorics of sound elements and the manifestation of permutations. Extrapolation of the principles of the game theory, with the 
focus on the principles of continuity in the piano creativities of A. Skryabin and M. Verykivsky, allowed to find manifestations of spontaneous and compositional-conscious processes in the their musical thinking.

\section{REFERENCES}

1. Akopyan, L.O. (1986). Iskhodnye printsipy formalizovannogo analiza muzykal'nogo teksta. In Strukturnyy analiz teksta: sb. statey AN Armyanskoy SSR, 2. Yerevan: AN Armyanskoy SSR (pp. 210-220).

2. Hominsky, J. (1975, 1979). Istorija gharmoniji ta kontrapunktu. Kyiv: Muzychna Ukraina. (Vols. 1, 2).

3. Kharchenko, Ye. (2009). "Fenomen ghry" u fortepiannykh miniatjurakh 1990-2000-kh rr. (na prykladi fortepiannykh tvoriv K. Cepkolenko, S. Piljutykova, I. Shherbakova). Naukovyi visnyk Natsionalnoi muzychnoi akademii Ukrainy imeni P. I. Chaikovskoho, 84: Kompozytor i suchasnistj, $130-142$.

4. Maksymenko, B.O. (2008). Ratsionalne ta intuityvne u tvori Vitaliia Hodziatskoho "Hra". Naukovyi visnyk Natsionalnoi muzychnoi akademii Ukrainy imeni P.I. Chaikovskoho, 73: Muzychna tvorchist ta nauka v istorychnomu prostori, 219-226.

5. Mukha, A.I. (1979). Protsess kompozitorskogo tvorchestva: problemy i puti issledovaniya. Kyiv: Muzychna Ukraina.

6. Nazaykinsky, Ye.V. (1982). Logika muzykal'noy kompozitsii. Moscow: Musyka.

7. Owen, G. (1971). Game Theory: translation from English. Moscow: Nauka.

8. Skrypnik, A. (2009). Fenomen aleatoriki v tvorchestve kompozitorov XX veka: estetiko-kul'turologicheskiy aspekt. Naukovyi visnyk Natsionalnoi muzychnoi akademii Ukrainy imeni P.I. Chaikovskoho, 75: Kompozytor i suchasne sotsiokulturne seredovyshche, 155-171.

9. Shurova, N.S. (1999). Vitaliy Godzyatskiy. Shtrikhi k portretu. Green Lamp, 3-4, 50-51.

10. Xenakis, Ia. (1971). Formalized Music thought and mathematics in composition. London: Indiana University Press, Bloomington.

\section{Information about the author: \\ Kateryna Fadyeyeva,}

Doctor of Arts, Associate Professor,

Professor of the General and Specialized Piano Department, Petro Tchaikovsky National Music Academy of Ukraine 1-3/11, Architect Gorodetsky str., Kyiv, 01001, Ukraine https://orcid.org/0000-0003-2329-469X 